\title{
GEOLOGY OF THE PITKÄSLÄHDE SPRING, WESTERN FINLAND, AND THE ENRICHMENT OF ELEMENTS FROM GROUNDWATER TO PEAT
}

\author{
KIMMO VIRTANEN
}

\begin{abstract}
VIRTANEN, KIMMO 1993. Geology of the Pitkäslähde spring, western Finland, and the enrichment of elements from groundwater to peat. Bull. Geol. Soc. Finland 65, Part 1, 41-48.

The Pitkäslähde spring is located in the south of Pattijoki municipality, western

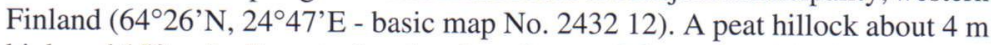
high and $150 \mathrm{~m}$ in diameter has developed around the spring. The flow route of groundwater in the peat deposit has been established with redox (Eh) measurements. In the course of thousands of years a large number of elements - $\mathrm{Ag}, \mathrm{Al}, \mathrm{As}, \mathrm{Ba}$, $\mathrm{Cd}, \mathrm{Co}, \mathrm{Cr}, \mathrm{Cu}, \mathrm{K}, \mathrm{La}, \mathrm{Li}, \mathrm{Mo}, \mathrm{Ni}, \mathrm{Pb}, \mathrm{Sc}, \mathrm{Ti}, \mathrm{V}, \mathrm{Y}$ and $\mathrm{Zn}$ - have precipitated from groundwater and become enriched in the peat deposit adjacent to the spring; $\mathrm{B}$, $\mathrm{Ca}, \mathrm{Fe}, \mathrm{Mg}, \mathrm{Mn}, \mathrm{Na}, \mathrm{P}, \mathrm{Sb}$ and $\mathrm{Sr}$, in contrast, have not been enriched in the peat.
\end{abstract}

Key words: spring, ground water, peat, bogs, enrichment coefficient, migration of elements, pH, Eh, Quaternary, Pattijoki, Finland.

Kimmo Virtanen: Geological Survey of Finland, SF-70701 Kuopio

\section{INTRODUCTION}

Pitkäsneva is a mire located in the south of

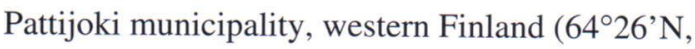
$24^{\circ} 47^{\prime} \mathrm{E}$ - basic map No. 2432 12). A peat hillock about $4 \mathrm{~m}$ high has formed around Pitkäslähde, a spring in the middle of the mire (Fig. 1). Peat hillocks like this are a rare geological formation. Similar, although much smaller, peat elevations have been reported from Gotland (Magnusson, et. al. 1963) and Finnish Lapland (Lahermo 1970, Lahermo et al. 1977).

\section{METHODS}

Survey lines were staked and levelled across Pitkäslähde. Peat samples were taken from the lines with a Russian peat sampler and studied in the field for peat types and humification. The distances between the study points along the lines varied (5$40 \mathrm{~m}$ ). The peats and basal soil types around the spring were measured on fresh samples in the field for acidity $(\mathrm{pH})$ and redox potential (Eh). Some of the samples were treated in the laboratory, where they were dried $\left(\right.$ at $\left.105^{\circ} \mathrm{C}\right)$, ground, ashed $\left(\right.$ at $\left.450^{\circ} \mathrm{C}\right)$, dissolved in 6- $\mathrm{M} \mathrm{HCl}$ solution and analysed for 30 elements by ICP.

\section{SITE}

Pitkäsneva mire, with Pitkäsjärvi lake in the middle of it, covers about 700 ha. The central part of Pitkäsneva is occupied by an extensive waterlogged, oligotrophic raised bog mainly composed of Sphagnum cuspidatum bog with hollows. The latter is surrounded by tall-sedge fen, 


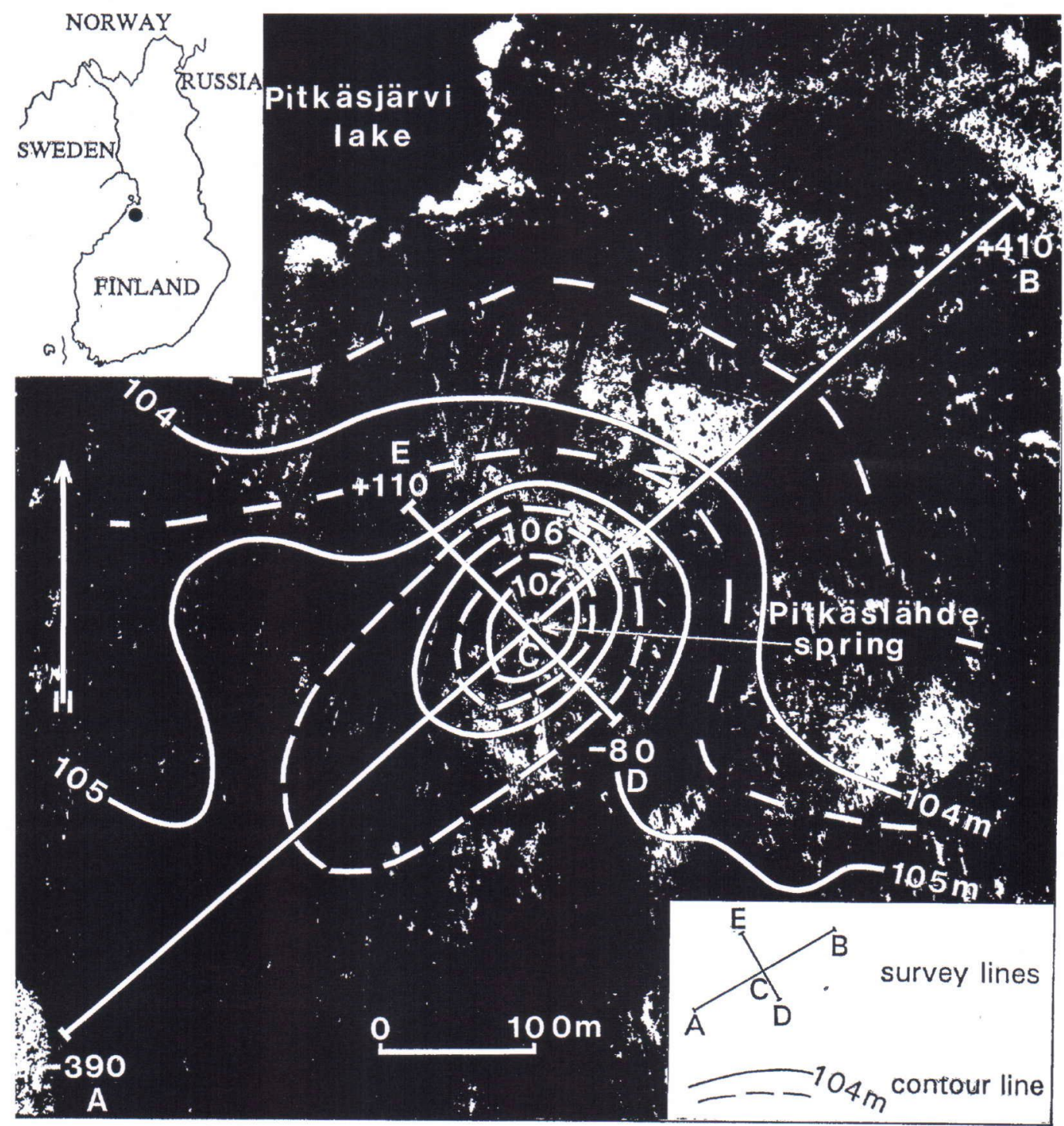

Fig. 1. An aerial photo of Pitkäslähde spring and its surroundings (Photogrammetric Division 1990), with inserted study lines and the contours around the spring. Peat growth has been intense adjacent to Pitkäslähde, forming a hillock around it. (Published by permission of National Board of Survey.)

Sphagnum papillosum bog, flark fen and low-sedge bog. Cottongrass pine bog, Sphagnum fuscum bog and tall-sedge bog are the predominant cover types in the margins of the mire and in the area south of Pitkäsjärvi lake (Virtanen 1985).

The ${ }^{14} \mathrm{C}$ date of a sample from the centre of the mire shows that Pitkäsneva started to paludify $7070 \pm$
130 years ago (BP) (SU - 1491) after the area had emerged from beneath the sea. The average thickness of the peat deposit is $2.5 \mathrm{~m}$, and the maximum thickness $6.2 \mathrm{~m}$. Carex-dominant peat accounts for c. $60 \%$, and Sphagnum-dominant peat for $39 \%$ of peats; Bryales-dominant peats account for less than 1\%. Eriophorum and Scheuchzeria are the most 
common codominant components in Sphagnum peats, and Equisetum, wood remains and Scheuchzeria in Carex peats. In the south of the mire there is Bryales peat (Virtanen 1985).

The Pitkäslähde spring, which developed in the middle of the mire, lies southeast of Pitkäsjärvi lake. The spring, which is about $0.5 \mathrm{~km}$ from the edge of the mire is a rounded, 'crater-like' clearwater pool, $7 \mathrm{~m}$ in diameter and a few metres deep. Some outlet channels of groundwater in peat emerge on the bottom of the spring. A peat hillock, about $150 \mathrm{~m}$ in diameter and rising about $4 \mathrm{~m}$ above the surrounding mire surface, has formed around the spring (Fig. 1). The water level in the spring is at the elevation of the top of the peat hillock and is thus several metres above the water table in the surrounding mire. Consequently, there is persistent overflow from the spring to the mire.

The islands in Pitkäsneva and the areas west and north of it are boulder-strewn ablation till. The areas south and east of the mire are also till terrain. The source of the water flowing from Pitkäslähde has not been established. The water may derive either from a bedrock fracture or from an probable till-covered esker south of the spring. Such eskers are common in this part of Finland (e.g. Iisalo 1992).

\section{RESULTS}

\section{Biostratigraphy of the peat deposit}

The peat layer in the hillock around the spring is over $6 \mathrm{~m}$ at its thickest, but in the surrounding mire it is only 2-3 thick. There is a wide variety of peat types in the hillock (Fig. 2). The bulk are poorly humified mesotrophic and eutrophic Carex peats with abundant Bryales remains, but interlayers, 2$60 \mathrm{~cm}$ thick, of poorly humified Paludella and Scorpidium peat are common. There are also layers of loose Sphagnum papillosum peat, and, in the upper part of the hillock, numerous compact interlayers of slightly humified Sphagnum fuscum peat. Other common plant remains that can be recognized are Phragmites australis, Menyanthes trifoliata, Potentilla palustris, Equisetum and Scheuchzeria palustris as well as the remains of bog shrubs. The peat contains abundant remains of wood, e.g. Pinus, Alnus and Betula.

The wood-bearing peat layers are watery and composed exclusively of wood and well-humified peat humus. These wood and peat humus layers are small in surface area and criss-cross the peat hillock around the spring, forming permeable subsurface 'drains' that permit water to flow in the peat. Some of the drains bring water to the spring whereas others conduct the water to the surrounding mire.

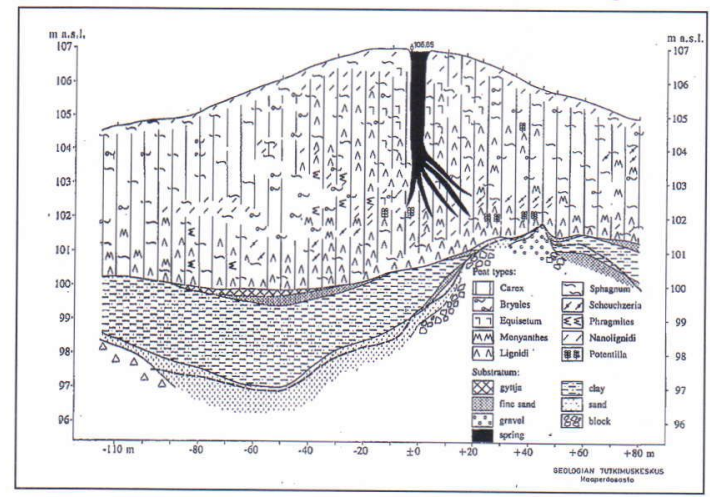

Fig. 2. Groundwater discharges into Pitkäslähde from a peat-covered gravel hummock about $40 \mathrm{~m}$ from the spring. From there water flows within the peat to the spring. A cross-section of study line $D-E$.

These drains developed from former seepage channels, from which the groundwater used to seep through the peat to the mire. In the course of time peat grew over the channels, and they remained inside the hillock. Alnus incana, Juniperus communis, various Salix species, herbs, Sphagnum warnstorfii and Aulacomnium palustre grow in abundance in the vicinity of the present groundwater seepage channels. Drains in peat deposits have also been described from blanket bogs in Scotland and from raised bogs in Germany (Ingram 1983).

The surroundings of the spring were formerly mesotrophic or eutrophic in mire type, but some decades ago an outlet ditch was dug from the spring. As a result the surface of the hillock dried and it turned into Calluna-Sphagnum fuscum pine 
bog. The groundwater which seeps through the peat in places keeps the vegetation minerotrophic. Small Scorpidium and Drepanocladus stands are still encountered within range of the groundwater.

\section{Mineral soil of the mire bottom}

In places under the peat there is a gyttja layer, about $10 \mathrm{~cm}$ thick, containing mineral matter (Fig. 2). This is underlain by $5-20 \mathrm{~cm}$ of grey, compact fine sand (Fig. 2), and this in turn by a layer of grey, soft clay, which at the spring is $240 \mathrm{~cm}$ thick (Fig. 2). The fine-grained sediments rest on sand. The surficial part of the sand has been reduced and is grey in colour. Deeper down it has been oxidized by groundwater and has turned brown. The grey sand layer is from 1 to 60 $\mathrm{cm}$ thick. Groundwater discharges under the peat from a hummock of sand, gravel and stones that rises through the fine-grained sediments of the mire bottom into the peat (Fig. 2).

The mineral matter in the mire bottom adjacent to the spring contains abundant rust, and in some places there is a rust layer, a few centimetres thick, between the mineral soil and the peat.

\section{Morphology of the spring}

Groundwater discharges from a hummock composed of sand, gravel and boulders overlain by peat, that penetrates the fine-grained sediments of the mire bottom and is thus in direct contact with the peat (Fig. 2). The groundwater discharges from the mineral soil to the peat at a site about 40 m southeast of the spring. From there it runs to the spring along 'drains' in the peat.
Oxygen-bearing groundwater transporting mineral substances has kept the vegetation around the spring dense and lush. The poorly humified peat formed from plant remains has gradually grown into a compact, poorly permeable hillock around the spring. The composition of the plant remains implies that the intense overflow of groundwater from the spring has kept the surface of the hillock wet and thus prevented humification and microbiological decomposition of the peat. As groundwater discharge has been continuous, peat has not been able to cover the spring. (The volume of water discharging from the spring cannot be

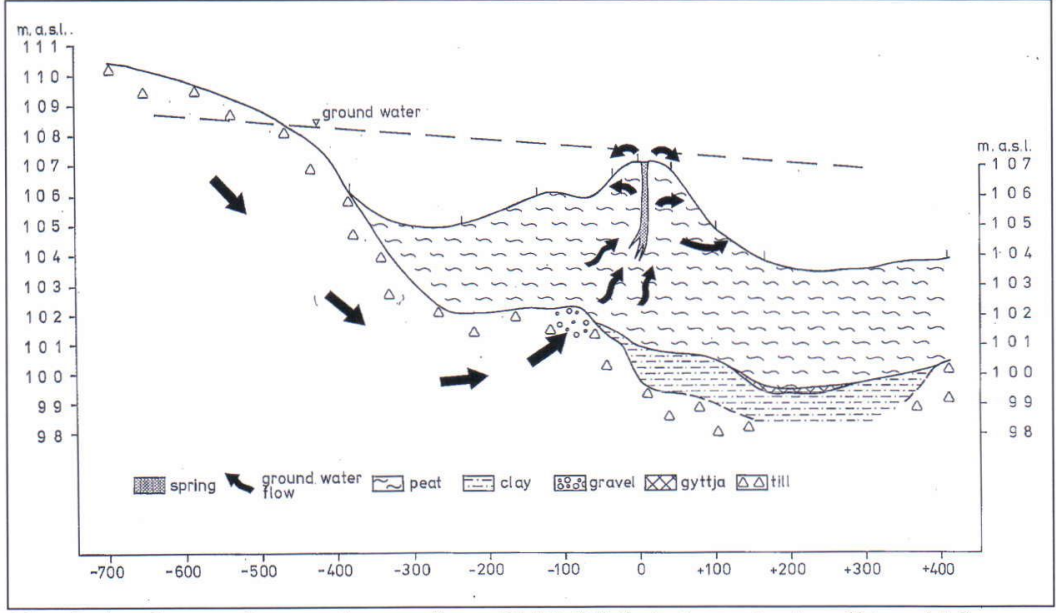

Fig. 3. A scheme of groundwater flow. Pitkäslähde is 'artesian' well in which confined groundwater discharges from below impermeable layers, rising higher in the spring than elsewhere on the mire.

assessed as water seeps through the peat along several routes.)

The water level of Pitkäslähde spring is about 4 $m$ higher than in the rest of the mire due to the fact that the confined groundwater has turned the spring into a kind of artesian well. The combined influence of the compact till and clay layer at the mire bottom and the poorly permeable peat is such that the confined groundwater from an extensive area is discharged at only one site, i.e. in the mineral soil hummock described above. From there the groundwater discharges into the peat and then flows along the drains in the peat to the spring (Fig. 3). Lahermo (1970) has described a similar type of 
spring from Lapland in which the groundwater flows in mineral soil under peat and discharges into a mire, where it forms a peat hillock.

\section{Results of $\mathrm{pH}$ and Eh measurements}

In the immediate surroundings of Pitkäslähde the $\mathrm{pH}$ values of peat are high, usually $4.5-6.8$. However, on the mire surface, which is dry in parts, the $\mathrm{pH}$ is less than 4.5. On the surface of the peat deposit, the $\mathrm{pH}$ values of the peat are lower but gradually increase towards the bottom of the deposit. The water in the spring has a $\mathrm{pH}$ of 6.5 on the surface and of 6.3 at a depth of $1 \mathrm{~m}$.

In the mineral soil under the peat the $\mathrm{pH}$ values are frequently slightly higher than in the peat, ranging from 6.2 to 7.2 . The $\mathrm{pH}$ in the fine sand at the mire bottom increases as a function of depth as does the $\mathrm{pH}$ of the peat. As a rule the $\mathrm{pH}$ is slightly higher in the grey, reduced mineral soil of the mire bottom than in the underlying brown, oxidized mineral soil.

Redox (Eh) survey data on Pitkäslähde indicate the location of the groundwater flow routes fairly well because the groundwater is much richer in oxygen than is the water in peat (Fig. 4). The Eh value measured on Pitkäslähde water was +310 $\mathrm{mV}$. In the peat affected by the spring water and in the surficial peat partly dried by draining, the Eh values are $+150-+250 \mathrm{mV}$, but in peats not affected by oxygen-rich groundwater the Eh values are +10 $-+150 \mathrm{Mv}$. In the brown mineral soil oxidized by groundwater the Eh values range from +150 to $+250 \mathrm{mV}$, whereas in the grey mineral soil unaffected by groundwater the $\mathrm{Eh}$ is $-60-+70 \mathrm{mV}$ (Fig. 4).

\section{Elements in peat within the range of the spring}

Some of the elements have been enriched in peat close to the spring whereas others show the same abundances as elsewhere in the mire. The enriched elements are $\mathrm{Ag}, \mathrm{Al}, \mathrm{As}, \mathrm{Ba}, \mathrm{Cd}, \mathrm{Co}, \mathrm{Cr}, \mathrm{Cu}, \mathrm{K}, \mathrm{La}$, $\mathrm{Li}, \mathrm{Mo}, \mathrm{Ni}, \mathrm{Pb}, \mathrm{Sc}, \mathrm{Ti}, \mathrm{V}, \mathrm{Y}$ and $\mathrm{Zn}$ (Figs 5-8).

The concentrations of $\mathrm{La}$ and $\mathrm{Y}$ are 500 times

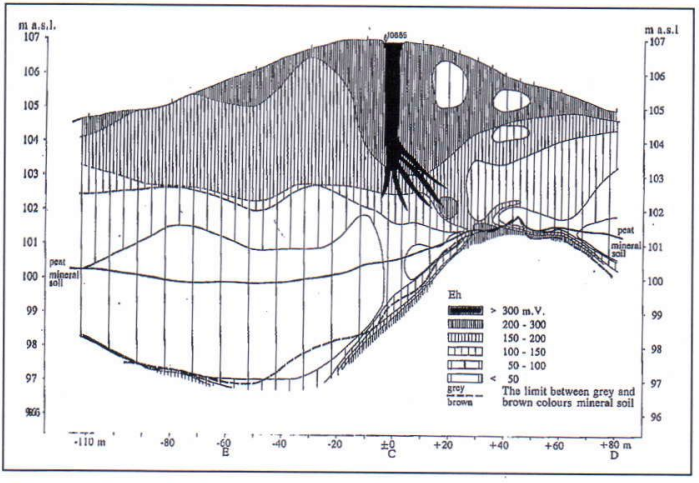

Fig. 4. The discharge route of groundwater from the mineral soil through peat into the spring and then away from the spring is reflected as elevated Eh values in the peat deposit. A cross-section of study line D-E.

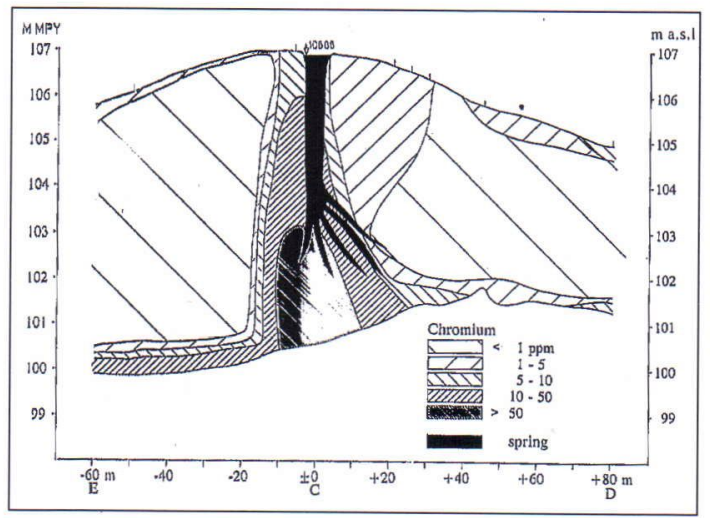

Fig. 5. The concentration of chromium in the peat near the spring is 50 times higher than in peat elsewhere. An example of an element enriched in peat from the spring. A cross-section of study line D-E.

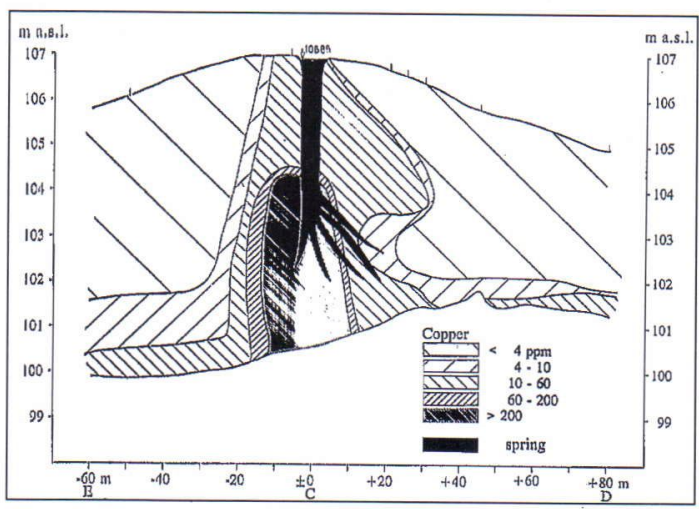

Fig. 6. The concentration of copper in peat near the spring is 100 times higher than in peat elsewhere. An example of an element enriched in peat. A crosssection of study line D-E. 


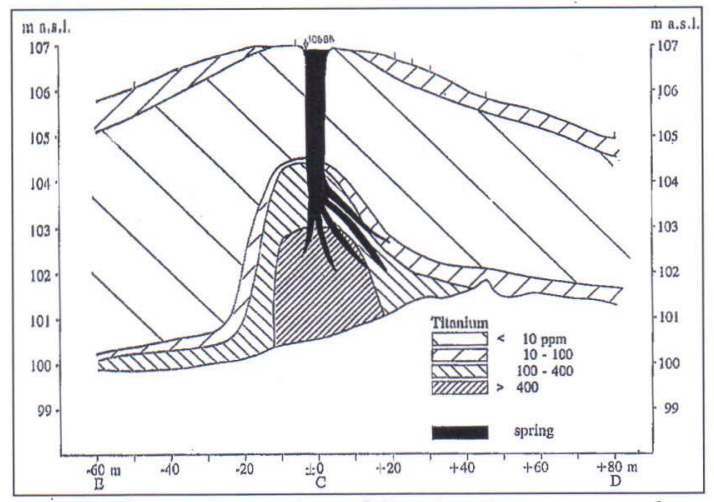

Fig. 7. The concentration of titanium in peat near the spring is 60 times higher than in peat elsewhere. An example of an element enriched in peat. A crosssection of study line $D-E$.

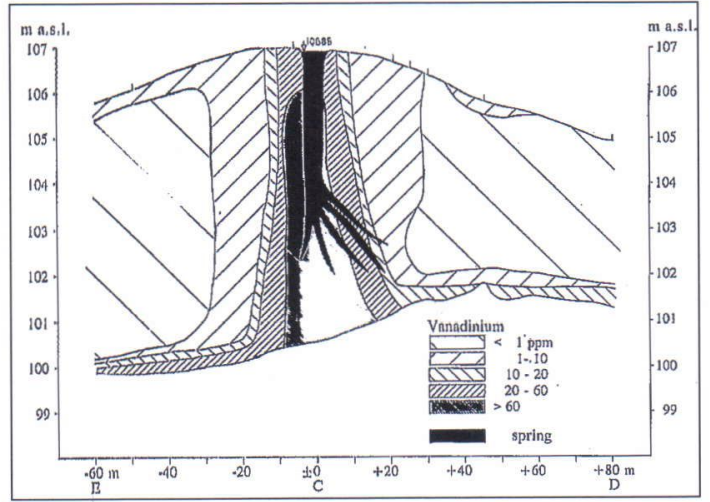

Fig. 8. The concentration of vanadium in peat near the spring is 70 times higher than in peat elsewhere. An example of an element enriched in peat. A crosssection of study line D-E.

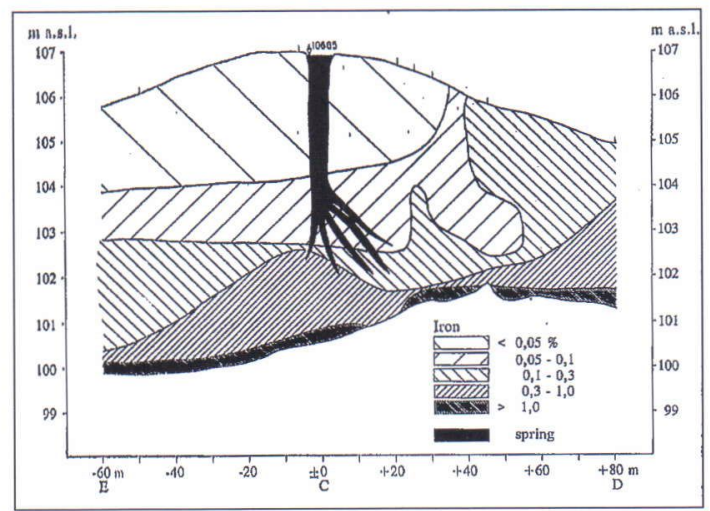

Fig. 9. The concentration of iron in peat near the spring is about the same as in peat elsewhere. An example of an element not enriched in peat. A crosssection of study line D-E. and those of Li, Ti, Cd, Cu, Pb, Cr, V and Ag 50-100 times higher than those in peat further away from the spring. The ash contents of peat are also higher adjacent to the spring than elsewhere in the mire. Elements not notably enriched near the spring are: B, Ca, Fe, Mg, Mn, Na, P, Sb and Sr (Fig. 9). Data on the elemental concentrations with their enrichment coefficients are given in Table 1. Excluding the enrichment near the spring, the metal concentrations of peat at the study site are of the same order of magnitude ( $\mathrm{Cu}, \mathrm{Fe}, \mathrm{Ni}$ and $\mathrm{Zn}$ ) as in the other mires in the area or lower $(\mathrm{Co}, \mathrm{Cd}, \mathrm{Mn}$ and $\mathrm{Pb})$ (He \& Virtanen 1991).

\section{DISCUSSION}

Pitkäslähde spring formed at its present site when the discharge of groundwater confined by impermeable fine-grained sediments and till concentrated from extensive areas at one spot in a hummock of coarse-grained mineral soil. Poorly humified peat gradually grew into a compact hillock around the spring. The intense flow of groundwater from the spring has kept the surface of the peat hillock continuously wet and thus hindered humification and biological decomposition of peat, as peat decomposes in the surficial layers of mire mainly as a result of oxidation (Lähde 1969).

Pitkäslähde spring has been in existence for thousands of years as can be deduced from the age of Pitkäsneva mire $\left({ }^{14} \mathrm{C} 7070 \pm 130 \mathrm{yr} \mathrm{BP}-\mathrm{Su} 1491\right)$ and from the stratigraphy of the spring area. During that time, large amounts of elements have discharged into the mire along with the water from the spring. Many of these elements have been enriched in the peat around the spring in the same manner as reported by Hill et al. (1988) from Minnesota and by Owen et al. (1992) from Colorado. However, there are several elements that have not been enriched in peat around Pitkäslähde. As a rule, the higher the atomic weight and valence of the cations the better they are enriched in peat (Ibarra et al. 1979).

Elements are enriched close to a spring when 
Table 1. The contents and enrichment coefficients of elements.

\begin{tabular}{|c|c|c|c|c|c|c|c|}
\hline \multirow[b]{2}{*}{$\mathrm{Ag}$} & \multirow[b]{2}{*}{$\mathrm{ppm}$} & \multicolumn{3}{|c|}{ MIN - MAX } & \multirow{2}{*}{$\begin{array}{r}\text { MEAN }^{2} \\
0,03\end{array}$} & \multirow{2}{*}{$\begin{array}{c}\begin{array}{l}\text { ENRICHMENT }^{3} \\
\text { COEFFICIENT }\end{array} \\
50\end{array}$} & \multirow{2}{*}{$\begin{array}{l}()^{4} \\
(10)\end{array}$} \\
\hline & & $>0,02$ & - & 1,6 & & & \\
\hline $\mathrm{Al}$ & $\mathrm{ppm}$ & 88 & - & 16700 & 248 & 30 & (4) \\
\hline As & $\mathrm{ppm}$ & $>0,03$ & - & .25 & 0,8 & 20 & (2) \\
\hline B & $\mathrm{ppm}$ & 3,2 & - & 10,6 & 6,7 & 0,8 & \\
\hline $\mathrm{Ba}$ & ppm & 3,4 & - & 158 & 5,6 & 10 & \\
\hline $\mathrm{Ca}$ & $\%$ & 0,52 & - & 1,59 & 0,96 & 1,2 & \\
\hline $\mathrm{Cd}$ & $\mathrm{ppm}$ & $>0,01$ & - & 4,1 & 0,05 & 80 & \\
\hline Co & $\mathrm{ppm}$ & 0,2 & - & 21,7 & 0,28 & 10 & \\
\hline $\mathrm{Cr}$ & $\mathrm{ppm}$ & 0,2 & - & 63,3 & 0,9 & 50 & (6) \\
\hline $\mathrm{Cu}$ & $\mathrm{ppm}$ & 0,9 & - & 617 & 4 & 100 & (25) \\
\hline $\mathrm{Fe}$ & $\%$ & 0,02 & - & 2,15 & 0,14 & 1,5 & \\
\hline $\mathrm{K}$ & $\mathrm{ppm}$ & 39 & - & 3300 & 72 & 10 & \\
\hline $\mathrm{La}$ & $\mathrm{ppm}$ & $>0,04$ & - & 168 & 0,35 & 500 & (10) \\
\hline $\mathrm{Li}$ & ppm & $>0,03$ & - & 9,6 & 0,08 & 70 & \\
\hline $\mathrm{Mg}$ & $\%$ & 0,14 & - & 0,52 & 0,28 & 0,9 & \\
\hline $\mathrm{Mn}$ & $\mathrm{ppm}$ & 2 & - & 124 & 11 & 1,7 & \\
\hline Mo & $\mathrm{ppm}$ & 0,1 & - & 10,9 & 0,25 & 20 & \\
\hline $\mathrm{Na}$ & ppm & 90 & - & 680 & 0,01 & 2,5 & \\
\hline $\mathrm{Ni}$ & ppm & 0,9 & - & 146 & 4 & 35 & (15) \\
\hline$P$ & ppm & 105 & - & 882 & 230 & 2 & \\
\hline $\mathrm{Pb}$ & $\mathrm{ppm}$ & $>0,1$ & - & 28 & 0,25 & 100 & (20) \\
\hline $\mathrm{Sb}$ & ppm & $>0,16$ & - & 4,65 & 0,60 & 5 & \\
\hline Sc & ppm & 0,01 & - & 14,3 & 0,10 & 100 & (10) \\
\hline $\mathrm{Sr}$ & $\mathrm{ppm}$ & 52 & - & 125 & 76 & 2 & \\
\hline $\mathrm{Ti}$ & $\mathrm{ppm}$ & 4 & - & 867 & 5,9 & 60 & (10) \\
\hline V & ppm & 0,3 & - & 92,6 & 1,1 & 70 & (10) \\
\hline$Y$ & ppm & 0,1 & - & 263 & 0,5 & 500 & (20) \\
\hline $\mathrm{Zn}$ & $\mathrm{ppm}$ & 1,7 & - & 144 & 5,6 & 25 & \\
\hline
\end{tabular}

${ }^{1}$ All samples. $\mathrm{n}=32$

${ }^{2}$ Whitout samples of botom layer and close to the spring.

${ }^{3}$ Enrichment coefficient. Peat immediate close to the spring/Peat around the spring. Total peat layer.

${ }^{4}$ Enrichment coefficient. Peat immediate close to the spring/Peat around the spring. Bottom. peat layer.

they precipitate from groundwater as it discharges from mineral soil into peat. Consequently the $\mathrm{pH}$ of the groundwater falls and the Eh conditions become reducing. Moreover, in peat, groundwater encounters a fine-grained organogenic, $\mathrm{C}, \mathrm{N}$ and $\mathrm{H}$ bearing medium that is entirely different both chemically and physically from the $\mathrm{SiO}_{2}$-bearing coarsegrained mineral soil.

Under reducing conditions many of the elements, e.g. Ag, $\mathrm{Al}, \mathrm{As}, \mathrm{Ba}, \mathrm{Co}, \mathrm{Cr}, \mathrm{Cu}, \mathrm{Li}$, $\mathrm{Mo}, \mathrm{Ni}, \mathrm{V}$ and $\mathrm{Zn}$, are immobilized and are thus enriched adjacent to a spring (cf. Rose et al. 1979). However, some of the elements are almost immobile under acidic conditions and are thus enriched in the peat near a spring; these include $\mathrm{Ba}, \mathrm{Cr}$, La, Li, Ti and Y (cf. KapataPendias \& Pendias 1984).

The mobility of elements in spring water is not affected by $\mathrm{pH}$-Eh conditions alone but also by the exchange capacity of peat, the organic compounds of peat (Ibarra $e t$ al. 1979), bacterial activity and fungi (Moore et al. 1974). Since most of the metals are huminophilous they tend to be fixed to humic substance (Szalay 1964). The humic substances of peat (humines, and humic and fulvic acids) contain abundant $\mathrm{COOH}^{-}$and $\mathrm{OH}^{-}$groups and $\mathrm{C}=\mathrm{C}$ bonds (Tipping 1981) to which the elements transported by groundwater are fixed, thus giving rise to the elemental enrichments close to a spring (Ibarra et al. 1979). The elements enriched around a spring and fixed to organics include $\mathrm{Ag}, \mathrm{Co}, \mathrm{Cr}, \mathrm{Cu}, \mathrm{Li}, \mathrm{Mo}, \mathrm{Ni}, \mathrm{Pb}, \mathrm{V}$ and Zn (Kapata-Pendias 1984, Szalay 1964).

Some elements, such as B, Ca, Fe, Mg, Mn, Na and $\mathrm{Sr}$, are very mobile under acidic and reducing conditions (Brooks 1983, Rose et al. 1979) and 
have therefore not been enriched around the Pitkäslähde spring. The presence of a rust layer in the mineral soil at the bottom of the mire implies that, before the area was paludified, iron precipitated from the groundwater as a result of oxidation. After the peat deposit had formed, conditions became acidic and reducing. As the spring water was nonoxidizing, iron remained dissolved in water and

\section{REFERENCES}

Brooks R.R. 1983. Biological Methods of Prospecting for Minerals. New York $322 \mathrm{pp}$.

He Y. \& Virtanen K. 1991. The variation in water content and in concentrations in trace metals in peat in different mire types. Bulletin of the Geological Society of Finland 63, 121 - 128.

Hill, B.M. 1988. Relationship between Groundwater Flow and the Metals Content of Peat Lost River Peatland, Northern Minnesota. Eos 69, 353-354.

Ibarra J.V., Osacar J. \& Gavilan J.M. 1979. Retention of metallic cations by lignites and humic acids. Fuel 58, 827-830.

Iisalo E. 1992. Observations on the stratigraphy of Weichselian tills and subtill eskers in Central Ostrobothnia, Finland. Geological Survey of Finland, Report of investigation No. 112, 42pp.

Ingram H.A.P. 1983. Hydrology. In Gore, A.J.P. (ed.): Ecosystems of the World 4A (Mires: Swamp, Bog, Fen and Moor). Amsterdam, 67-158.

Kapata-Pendias A. \& Pendias H. 1984. Trace Elements in Soils and Plants. Boga raton, Florida. 314 pp.

Lahermo P. 1970. Chemical geology of ground and surface waters in Finnish Lapland. Bulletin de la Commission Géologique de Finlande 242. 106 pp. Lahermo P., Valovirta V.E. \& Särkioja A. 1977. The migrated with water away from the spring.

ACKNOWLEDGEMENTS: I thank Professors $R$. Kujansuu and V-P Salonen and Drs E. Lappalainen and E. Kukkonen for their constructive criticism and helpful comments on the manuscript. Mrs Gillian Häkli translated the text into English. Mrs Ritva Jokisaari and Mrs Riitta Turunen draw the figures. geobotanical development of spring-fed mires in Finnish Lapland. Geological Survey of Finland Bulletin 287. 44 pp.

Lähde E. 1969. Biological Activity in some Natural and frained peat soils with special reference to oxidation - reduction conditions. Acta Forestalia Fennica 94. $69 \mathrm{pp}$.

Magnusson N.H., Lundquist G. \& Regnell G. 1963. Sveriges geologi. Stockholm. $698 \mathrm{pp}$.

Moore, P.D. \& Bellamy D.J. 1974. Peatlands. Springer Verlag. New York. 221 pp.

Owen D.E., Otton J.K., Hills F.A. \& Schumann R.R. 1992. Uranium and Other Elements in Colorado Rocky Mountain Wetlands - A Reconnaissance Study. U.S. Geolgical Survey Bulletin 1992. 30 pp.

Rose A.W., Hawkes H.E. \& Webb J.S. 1979. Geochemistry in Mineral Exploration. Bristol. 657 pp.

Szalay E. 1964. Cation exchange properties of humic acids and their importance in the geochemical enviroment of UO2 and other cations. Geochémica et Cosmochémica Acta 28, 1605- 1614.

Tipping E. 1981. The aquatic humic substances by iron oxides, Geochémica et Cosmochémica Acta 45. 191-199.

Virtanen K. 1985. Pattijoella tutkitut suot ja niiden turvevarat. Geological Survey of Finland. Peat report 176. $163 \mathrm{pp}$. 